
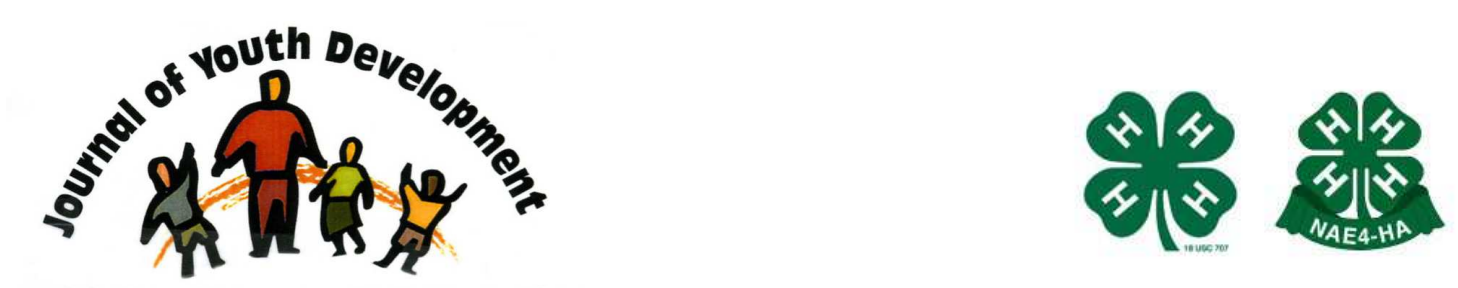

Bridging Research \& Practice

\title{
Explore the World with a Global Education Curriculum
}

\author{
Julie Tritz \\ WVU Extension Service - Wayne County \\ West Virginia University \\ Wayne, WV \\ julie.tritz@mail.wvu.edu \\ Tina Cowger \\ WVU Extension Service - Wayne County \\ West Virginia University \\ Wayne, WV \\ MaryBeth Bennett \\ WVU Extension Service - Wayne County \\ West Virginia University \\ Wayne, WV \\ Richard Fleisher \\ WVU Extension Service - Wayne County \\ West Virginia University \\ Wayne, WV \\ Doug Hovatter \\ WVU Extension Service - Wayne County \\ West Virginia University \\ Wayne, WV \\ Christina McCormack \\ WVU Extension Service - Wayne County \\ West Virginia University \\ Wayne, WV \\ Denis Scott \\ WVU Extension Service - Wayne County \\ West Virginia University \\ Wayne, WV \\ Veronica Wilcox \\ WVU Extension Service - Wayne County \\ West Virginia University \\ Wayne, WV
}




\title{
JOURNAL OF YOUTH DEVELOPMENT \\ bridging research and practice

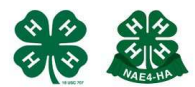

\section{Explore the World with a Global Education Curriculum}

\author{
Julie Tritz, Tina Cowger, MaryBeth Bennett, Richard Fleisher, Doug Hovatter, \\ Christina McCormack, Denis Scott and Veronica Wilcox \\ West Virginia University
}

\begin{abstract}
Recognizing and celebrating the diversity that exists in our communities has become a central goal of land-grant institutions and cooperative extension programs. This is coupled with the expectation that youth be equipped for a global workforce where they appreciate different world cultures, be able to evaluate global issues and challenges and understand the inter-connectedness of global systems. Given these points, a Global Education Curriculum developed by the WVU Extension Global Education \& Engagement Team is presented as a tool to instill a deeper understanding of and appreciation for cultures, people and global issues by youth and the adults who support them.
\end{abstract}

\section{Introduction}

Communities across the U.S. have become increasingly more diverse in the last 25 years. Recognizing and celebrating this diversity has become paramount in our land-grant institutions and cooperative extension programs. With no comprehensive Global Education Curriculum with age-appropriate lesson plans, Extension educators and youth development practitioners are left to search the Internet and other resources for ideas, programs or activities to celebrate diversity and to help bridge our understanding of different cultures and global issues. This article describes a promising curriculum being developed by the WVU Extension Global Education Team for use by extension educators and youth development professionals.

\section{The Need}

The USDA's National Institute for Food \& Agriculture (National Institute of Food \& Agriculture, 2012) recognizes the need of an international perspective. It notes that the success of the U.S. farm sector is increasingly dependent on our ability to trade and compete with other nations. It points to the importance of international research partnerships to address issues of food safety, sustainability, resource management, biotechnology and crop and livestock disease prevention. 
This means that youth today must develop a general acquaintance with the major geographical and cultural areas of the world, studying at least one other culture in some depth, and learning how to evaluate global issues (Etling, et al 2003). The curriculum holds promise in that it recognizes that our youth are entering a global workforce and expected to have a skill set that:

- Appreciates differences in food, geography, language, traditions, values, and the priorities of different countries,

- Evaluates global issues and challenges and problem-solve for possible solutions (examples: climate change and poverty),

- Understands the interconnectedness of global systems i.e. economic, social, cultural, racial, technological and ecological.

Given that U.S. youth are considered 'less geographically and culturally literate' than their equals in other industrialized nations (Carano and Berson, 2007), it is the WVU Extension Global Education \& Engagement Team's intent that this curriculum will inspire, motivate and encourage youth to learn about world cultures, people and the issues that impact them.

\section{Presentation of the Curriculum}

The curriculum is designed around five categories that include: agriculture and food; arts and history; communication, media and technology; geography and global issues. The following list provides more detail on each category.

\section{Agriculture \& Food}

Today's agriculture is dependent on the ability to trade and compete with other nations. International research in agriculture helps address national issues of food safety, resource management as well as crop and livestock disease prevention.

\section{Arts \& History}

Art and history encompasses a wide range of topics that allows the participant to learn of important periods and customs concerning a country or area which culminates in a comprehensive insight of the culture.

\section{Communication, Media \& Technology}

Advances in communication with respect to media and technology aids in making the world "smaller" and more connected. However, in order to become culturally savvy, it is imperative to note that communication encompasses a variety of ways such as body language, gestures and road signs.

\section{Geography}

With over 190 independent countries around the world, it is important to recognize that geography assists in cultural understanding and appreciation by not only identifying geographic links between countries, but historic relationships as well.

\section{Global Issues}

Awareness of current issues enables us to compare cultures, economic systems and social environments. Focusing on similarities encourages a connection between societies. It also emphasizes that diversity should be recognized and celebrated.

These categories were designed to place broad parameters for the curriculum as a whole. They support and compliment subjects taught in school as well as those subjects that are given less 
attention (or none at all) due to limited time and resources. The categories are also based on feedback secured from WVU Extension faculty.

The curriculum is comprised of skill-a-thons, which is a method of learning and is an approved WVU Extension curriculum design. A skill-a-thon is an educational lesson plan that is noncompetitive yet provides opportunities for the development of life skills to include: subject matter knowledge, self-awareness, decision-making, social interaction, and physical skills. Each skill-a-thon is designed around nine elements that include:

\begin{tabular}{|c|c|}
\hline Use & $\begin{array}{l}\text { Explains what educational event(s) the skill-a-thon will be most } \\
\text { appropriate for (ex. 4-H club meeting, camp setting, after school, in- } \\
\text { school programs, etc) }\end{array}$ \\
\hline Goal(s) & Describes the overall goal(s) of the skill-a-thon \\
\hline Time-frame & Describes how long the skill-a-thon will take to the complete \\
\hline Target age & Describes the target age the skill-a-thon is most applicable to \\
\hline $\begin{array}{l}\text { National } \\
\text { Content } \\
\text { Standards }\end{array}$ & $\begin{array}{l}\text { Lists national content standards which provide credibility for instructors } \\
\text { who want to use the curriculum in the school }\end{array}$ \\
\hline $\begin{array}{l}\text { Safety } \\
\text { precautions }\end{array}$ & $\begin{array}{l}\text { Describes any potential harm that may come to youth as a result of } \\
\text { doing the skill-a-thon (ex. food allergies) }\end{array}$ \\
\hline Activity & $\begin{array}{l}\text { Identifies the activity youth will do; this serves as the "title" for the skill- } \\
\text { a-thon }\end{array}$ \\
\hline Procedure & Describes in detail what steps are needed to complete the activity \\
\hline $\begin{array}{l}\text { Activity } \\
\text { discussion } \\
\text { questions }\end{array}$ & $\begin{array}{l}\text { Identifies several questions to help facilitate learning once the activity is } \\
\text { completed }\end{array}$ \\
\hline
\end{tabular}

The curriculum in its entirety is comprised of 19 skill-a-thons (approximately four skill-a-thons per category). It was approved by the WVU Extension Office of Communication and the WVU Extension 4-H Curriculum Specialist. Pre and post test evaluations were developed to measure the learning impacts of five skill-a-thons with plans underway to have evaluations developed for the remaining 14 skill-a-thons.

\section{Curriculum Impacts}

The interconnectedness of all aspects of life - food, entertainment, business, the economy, warrants that youth have an understanding of how these systems work in the United States and worldwide. Global education is no longer something that is an add-on or a luxury to be studied when time allows after 'academic subjects'. Rather, it is a necessity that can be seamlessly integrated into lessons already being taught.

With only $1.1 \%$, West Virginia has the lowest number per capita of foreign-born citizens in the United States (U.S. Census Data, 2003). Therefore, one has very few opportunities to be exposed to a different culture on a daily basis. While much attention has been paid to global education at the tertiary level, less emphasis has been placed on giving younger youth a global perspective. Most youth do not have the means to travel extensively, but a curriculum offers the potential to bring the world to them.

Five skill-a-thons were piloted with youth in five counties and at four state events and disseminated with 4-H educators and youth professionals at seven workshops from state to 
international levels. The tables below delineates where the curriculum was piloted and with whom.

\begin{tabular}{|l|l|l|}
\hline \multicolumn{3}{|l|}{ Piloting of Global Education Curriculum } \\
\hline & County & State \\
\hline Youth & Marion, Morgan, & 2011 4-H Teen Leader Weekend (WV) \\
Audiences & Preston, Putnam, & 2011 Alpha State 4-H Camp (WV) \\
& Tyler, Wayne (WV) & 2011 \& 2012 State TRiO Youth Leadership Conference \\
\hline
\end{tabular}

\begin{tabular}{|c|c|c|c|c|}
\hline \multicolumn{5}{|c|}{ Dissemination of Global Education Curriculum } \\
\hline & State & Regional & National & International \\
\hline $\begin{array}{l}4-\mathrm{H} \\
\text { Educators \& } \\
\text { Youth } \\
\text { Professionals }\end{array}$ & $\begin{array}{l}2011 \text { WV } \\
\text { Association of } \\
\text { Extension 4-H } \\
\text { Agents Spring } \\
\text { Conference (WV) } \\
2011 \text { Volunteer } \\
\text { Leader Weekend } \\
\text { (Jackson's Mill, } \\
\text { WV) }\end{array}$ & $\begin{array}{l}2012 \text { Tri-State } \\
\text { Diversity } \\
\text { Conference } \\
(\mathrm{OH})\end{array}$ & $\begin{array}{l}2012 \text { Public Issues } \\
\text { Leadership } \\
\text { Development } \\
\text { (Washington DC) } \\
2012 \text { National } \\
\text { Camping Institute } \\
(W V) \\
2010 \text { National } \\
\text { Association of } \\
\text { Extension 4-H Agents } \\
\text { Conference (AZ) }\end{array}$ & $\begin{array}{l}2010 \text { Delegation } \\
\text { from University of } \\
\text { Guanajuato, } \\
\text { Mexico }\end{array}$ \\
\hline
\end{tabular}

The pre and post tests conducted with the youth audiences illustrate that over $60 \%$ of participants reported increases in knowledge. Evaluation comments from youth demonstrate what they learned as a result of these skill-a-thons,

- $\quad$ "I learned how to budget a trip around the world"

- "I learned how other countries live without some of the luxuries we have."

- "I learned that $65 \%$ of the world's population does not have electricity."

Evaluations from 4-H educators and youth professionals indicate an enthusiasm to have educational resources available on the topic of global education. They also show how practical and useful the curriculum is as noted by some of the comments,

- "Great activities to share with 4-H Agents"

- "Skill-a-thons that I can also implement in my work!

- "I love the interactive experiences!"

Overall, the evaluation data illustrates the potential this curriculum has in bringing the world to thousands of youth in West Virginia who may otherwise not have the opportunity to travel outside the United States. It also illustrates an interest by youth educators to teach global education and instill a deeper understanding of and appreciation for cultures, people, and global issues.

\section{Program Replication}

Program replication helps to demonstrate the effectiveness of a program and under what circumstances. In this regard, The WVU Extension Global Education and Engagement Team seek Extension educators and youth development professionals interested in piloting for one year. The curriculum will be made available by contacting the authors. We plan to finalize the 
skill-a-thons through the National 4-H Curriculum process in order to offer them as a resource on the national level.

Our strategy to encourage replication is based on the "Seven Activities for Enhancing the Replicability of Evidence-Based Practices" (Metz, Bowie, and Blase, 2007). The authors of this article describe the essential role of core components in the replication process, focusing on the most essential and indispensable components for implementing the curriculum and achieving participant outcomes. Our evaluation goal is to achieve and document impacts that last, thus enhancing sustainability and efficacy for replication.

While our perspective emanates from 4-H youth development practices, other youth organizations such as Boy Scouts, Girl Scouts, Boys and Girls Clubs, parks and recreation program and others can benefit from use of this curriculum. The skill-a-thons are a fun, active, and challenging learning tool for a youth group of almost any size, age, or ability. This teaching method helps youth develop both life and project skills. A skill-a-thon can work well in most youth development learning environments such as classes, group meetings, afterschool sessions, club gatherings, fairs, and field trips. Learning-by-doing, the experiential learning process is a cornerstone of youth development educational practices. The litmus test will be that we provide sufficient detail so that others can replicates our approach.

\section{Conclusion}

The W.K. Kellogg Commission's concept of the "engaged institution" requires land-grant educators to see community in the context of the global village. Extension's responsibility is to help our citizens to become globally aware. This means seeing and understanding that the U.S and our citizens are part of the global dimension and not separate from it.

Our mission needs to incorporate the requirements of a changing environment, one that is now characterized by global interrelationships and increasing cultural diversity. One of the lessons learned since the turn of the century is the work that Extension does and the information we provide must achieve the excellence necessary to be competitive in a global community.

It is imperative to see and understand that the United States and its citizens are part of the global dimension and not separate from it. In order to accomplish these ideals, and increase global awareness and global leadership skills, the Global Education Curriculum aims to reach youth through a variety of programs and initiatives.

\section{References}

Etling, A., Reaman, K., \& El Sawi, G. (1993). Overcoming barriers to a global outlook in 4-H. Journal of Extension, 31: 2. http://www.joe.org/joe/1993summer/intl2.php

Carano, K.T., \& Berson, M.J. (2007). Breaking stereotypes: Constructing geographic literacy and cultural awareness through technology. The Social Studies, 65-70.

Metz, A.J.R., Bowie, L., \& Blase, K. (2007). Seven activities for enhancing the replicability of evidence-based practices. Research-to-results brief. Child Trends, 1-6. 
National Institute of Food \& Agriculture. (2007).

http://www.csrees.usda.gov/nea/international/international.cfm

National Institute of Food \& Agriculture. (2012).

http://www.csrees.usda.gov/globalengagement.cfm

U.S. Census Bureau. (2003). The Foreign Born Population: 2000, Census 2000 Brief. Retrieved February 15, 2011 from http://www.census.gov/prod/2003pubs/c2kbr-34.pdf

(C) Copyright of Journal of Youth Development $~$ Bridging Research and Practice. Content may not be copied or emailed to multiple sites or posted to a listserv without copyright holder's express written permission. Contact Editor at: patricia.dawson@oregonstate.edu for details. However, users may print, download or email articles for individual use.

ISSN 2325-4009 (Print); ISSN 2325-4017 (Online) 